\title{
Gallbladder Cancer TNM Finding v7
}

National Cancer Institute

\section{Source}

National Cancer Institute. Gallbladder Cancer TNM Finding v7. NCI Thesaurus. Code C90204.

A finding about one or more characteristics of gallbladder cancer, following the rules of the TNM AJCC v7 classification system. Carcinoid tumors and sarcomas are not included. The cystic duct is now included in this classification scheme. (from AJCC 7th Ed.) 